Table 3. The Dutch maintained a good average, for their size, at $\mathbf{5 \cdot 4 3}$ per litter, which is explained by nineteen of these litters being from outcrosses averaging $5 \cdot 58$, whilst the average from Dutch $\times$ Dutch matings was 5.11. The range for Dutch $\times$ Dutch litters was 4-7 but was more than doubled when outcrossed, ranging from 1-9 young, which, surprisingly, is greater than from the larger type does from the Flemish outcrosses.

TABLE 3. DISTRIBUTION OF LITTER SIZE BY BREED.

\begin{tabular}{|c|c|c|c|c|c|c|}
\hline Litter size & Flemish & $\begin{array}{c}\text { Flemish } \\
\text { first } \\
\text { cross }\end{array}$ & $\begin{array}{l}\text { Com- } \\
\text { bined }\end{array}$ & $\begin{array}{c}\text { Beveren } \\
\text { type }\end{array}$ & Dutch & Total \\
\hline 1 & - & 1 & 1 & - & 1 & 2 \\
\hline$\hat{2}$ & 1 & 2 & 3 & 2 & $\hat{1}$ & 6 \\
\hline 3 & 2 & 1 & 3 & 3 & $=$ & 6 \\
\hline 4 & - & - & - & 5 & 7 & 12 \\
\hline 5 & 4 & 2 & 6 & 5 & 5 & 16 \\
\hline 6 & - & 2 & 2 & 6 & 6 & 14 \\
\hline 7 & - & 1 & 1 & 8 & 5 & 14 \\
\hline 8 & 1 & 3 & 4 & 2 & 2 & 8 \\
\hline 9 & - & - & - & $=$ & 1 & 1 \\
\hline 10 & - & - & - & - & - & - \\
\hline 11 & 1 & - & 1 & - & - & 1 \\
\hline Total & 9 & 12 & 21 & 31 & 28 & 80 \\
\hline
\end{tabular}

A guide to the weight of different groups of does is taken from their live weights during lactation at approximately the time when the young began to leave the nest: Flemish, $9 \mathrm{lb} .6 \mathrm{oz}$; Flemish and first cross, $8 \mathrm{lb}$. $13 \cdot 13 \mathrm{oz}$. (Flemish $\times$ Belgian, $8 \mathrm{lb} .11 .67 \mathrm{oz}$. , and Flemish $\times$ Tan, $7 \mathrm{lb} .3 .00 \mathrm{oz}$.$) ;$ Beveren, 7 lb. $0.47 \mathrm{oz}$; Dutch, $4 \mathrm{lb} .14 \cdot 00 \mathrm{oz}$. It will be seen that popular varieties of fur and fancy breeds bred more freely than giants. Furthermore, after weaning, the small types were ready for further breeding sooner, and more readily, than large heavy animals.

\section{Conclusion}

The Flemish Giant is the largest breed of rabbit, but it is slothful and more difficult to breed than either the medium-sized fur breeds or the small fancy breeds (for example, Beverens and Dutch), when fed and managed under similar conditions.

First crosses from Flemish were fertile, irrespective of whether the cross was to large or to small breeds.

After an abnormally severe winter, which resulted in changes of diet, the average litter size of larger types was lower than expected and nearer the level for small breeds.

${ }^{1}$ Standard. Flemish Giant Rabbit Club, London.

${ }^{2}$ Wilson, W., King, and McCartney, W., "Rabbit Feeding for Meat and Fur', Imperial Bureau of Animal Nutrition, Aberdeen, Teehnical 'Communication No. 12 (1940).

"Pickard, J. N., "A Preliminary Study of Some of the Factors Influencing the Duration of Pregnancy and Litter Size in the Rabbit," IVth World's Poultry Congr. Papers, Section F, 901 (1931). 4 Rosahn, P. D., Greene, H. S. N., and Hu, C. K., Proc. Sor. Exp.
Biol. and Med., 31, 1214 (1934),

${ }^{5}$ Punnett, R. C., and Bailey, P. G., J. Genet., 8, 1 (1918).

${ }^{6}$ Pease, M. S., J. Genet., 20, 261 (1928).

' Castle, W. E., "Size Inheritance in Rabbit Crosses", Carnegie Inst., Washington, Pub. No. 320, 3 (1922).

8 Wilson, W. King, J. Heredity, 27, 127 (1936).

- Wilson, W. King, "Alternative Modes of Inheritance of Steel Grey Coat Colour in Rabbits", VIIth Internat. Genet. Congr., Section D, 1939 .

${ }^{10}$ Punnett, R. C., J. Genet., 2, 221 (1912).

${ }^{11}$ Punnett, R. C., J. Genet., 5, 37 (1915).

12 Punnett, R. C., J. Genet., 23, 265 (1930).

${ }^{13}$ Pap, E., Z. Induktiv. Abstammungs- und Verebungs-lehre, 26, 185 (see 14) (1921).

${ }^{14}$ Onslow, H., J. Genet., 12, 91 (1922).

15 Hammond, J., "Reproduction in the Rabbit" (Edinburgh : Oliver and Boyd, 1925).

\title{
BICENTENARY OF HENRY CORT
}

$\mathrm{O}^{\mathrm{r}}$ F the leading contributors to the advancement of British industries in the latter half of the eighteenth century, Henry Cort is the one of whom we know least. It is generally stated that he was born near Lancaster in 1740 , and to mark his bicentenary, at a meeting of the Newcomen Society on November 13, Dr. H. W. Dickinson read a paper giving much new information about the inventor and his activities. Though nothing is known of Cort's education and early life, by 1765 he had established himself in London as a Navy agent, having an address in Crutched Friars in the east of the City, in which also was a Navy pay office. The district was one familiar to Pepys and has many associations with the Navy of bygone days. A Navy agent was a banker and attorney who acted for H.M. ships as to pay, allowances, prize money, salvage and such like; and it was Cort's connexion with the Navy which ultimately led to his becoming an iron master.

From 1765 Cort slowly emerges from the obscurity of his early life. In 1768 he married a niece of a Mr. Attwick who had contracted to supply mooring chains and other iron naval stores to Portsmouth Dockyard, but who in 1772 assigned his contract to a Mr. Morgan, who had a forge at Fontley, in the parish of Titchfield, two miles from Fareham at the north-west corner of Portsmouth Harbour. Britain at this time was largely dependent on Sweden for its wrought iron, and Morgan's work consisted more in remaking old wrought iron into new articles than in the production of the iron itself. From the beginning of the eighteenth century a forge had been in existence at Fontley, where there was a tilt hammer worked by water-power and an adequate supply of charcoal. Morgan being in financial difficulties, Cort came to his assistance, and in 1775 took over the management of the concern. Under Cort, the works were improved and the profits considerable. In spite of this there was further need for capital, and Cort accordingly secured the help of Adam Jellicoe who, while pay clerk at Portsmouth, had acted as his agent.

By 1781-83 the works were engaged on the conversion of considerable quantities of old iron mast-hoops into new hoops, and it was then that Cort made a variety of experiments and took out the first of his two memorable patents. The date of this patent, No. 1351, was January 17, 1783. It was for "A New Mode and Art of Shingling, Welding and Manufacturing Iron and Steel into Bars, Plates, Rods and otherwise, of Pure Quality, in large Quantities by a more effectual Application of Fire and Machinery, and with greater Yield, than any Method before attained or put in practice." "In the specification Cort further described passing the heated iron through 
the rollers of a common rolling mill and the making of bars, bolts, half flats, etc., by the use of rollers with grooves and collars."

Thirteen months later Cort secured his other patent, No. 1420, of February 13, 1784, for "A Peculiar Method and Process of Preparing, Welding, and Working various Sorts of Iron, and of reducing the Same into Uses by Machinery," in which he described the process afterwards known as "dry puddling", a process which, using coal instead of charcoal, was destined to be of immense importance to the iron industry. In examining Cort's practices and patents, Dr. Dickinson eame to the conclusion that there could be no doubt that the patents are simply a recapitulation of the technique Cort was carrying out at Fontley. Cort, of course, was not alone in his endeavours to improve the production and working of iron, but after reviewing the efforts of his contemporaries Dr. Dickinson concluded that "what we can say of Cort was that he gathered existing knowledge and technique, absorbing what was useful and necessary for his purpose, rejecting what was not needed, and combining it into a system which, as a whole, constituted such an advance that it marked an entirely new era in the manufacture of wrought iron. The effect of his labours was immediate; whereas a tilt hammer had been able to produce a ton of bars in 12 hours, no less than 15 tons could be passed through the rolls in the same time; the iron, produced as it was entirely by pit coal, was of a quality that enabled it to compete for all but the most exacting requirements with the charcoal iron of Sweden, Russia and New England. The process enabled Great Britain, relying on mineral fuel, to advance within a decade to the premier iron-producing country of the world."

Contracts from the Navy Board continued to come to Cort and Jellicoe, and Cort travelled to many places to assist iron makers to instal his rolls and puddling furnaces. If all had gone right he should have gained a fortune comparable to that later enjoyed by Bessemer. It has been the lot of many inventors to see the financial rewards due to them slip through their fingers, but none of them, perhaps, was treated more unkindly by fate than Cort. Five years after his patent of 1784 , which afterwards led to the construction of puddling furnaces by the thousand, Adam Jellicoe died and his papers showed that he was in default to the Navy for no less than $£ 39,676$. There being then no limited liability, the works were seized, no effort was made to exploit the patents, and Cort was reduced to bankruptcy. With a numerous family Cort was left to struggle along as best he could, save that in 1791 he was granted a Government pension of $£ 200$ a year, which with reductions for fees amounted to little more than $£ 160$. Nine years later, on May 23, 1800, he died and was buried in Hampstead Churchyard, his death passing with no notice save a couple of lines in the Gentleman's Magazine.

Such is briefly the outline of the story Dr. Dickinson had to tell. Many famous men were interested in Cort's work, including Black, James Hutton and Watt, and the latter wrote of Cort as he knew him at the age of forty-four that "he seems a simple goodnatured man, but not very knowing." Though neglected in his day, Cort has not wanted for admirers in our own times, and it was through an American ironmaster, Charles H. Morgan (1831-1911), that Cort's tombstone in Hampstead Churchyard was renovated and a bronze tablet placed in the porch of the church saying that to Cort "the world is indebted for the arts of refining iron by puddling with mineral coal and of rolling metals in grooved rolls". Introduced in a period when the steam engine was making rapid strides, when men were experimenting with iron boats, steam-boats, locomotives, and iron railroads, and when iron was being widely used as a material for construction, Cort's improvements enabled our ironmasters to meet all the rapidly growing needs of the pioneers of the modern engineering world, and his methods were not superseded until the labours of Bessemer, Siemens, Martin and others ushered in the age of steel.

\section{SOIL BACTERIA AND WAR WOUNDS}

\section{By Dr. Hugh Nicol}

\begin{abstract}
A SURGICAL development which evolved on a large scale in the recent Spanish Civil War is the treatment of dirty and often comminuted and complicated fractures by immobilization in a plaster cast. The cast is applied immediately after the wound has been made 'mechanically' clean by removal of bone and metal splinters and fragments of clothing and other foreign matter and by resection of all dead tissue that can be found; no antiseptic is applied to the wound itself. Subject to this preliminary cleansing and to the provision of traction and drainage as necessary, no other treatment is given during the month or so during which the first cast is in position ; the plaster is then changed, and the second cast is allowed to remain for some weeks, after which union and healing are usually remarkably complete.

The success of the treatment depends on ignoring the bacterial processes such as surgeons normally take great pains to combat by the use of antiseptics, irrigation, and frequent changes of dressings : it has
\end{abstract}

been found that, given the initial surgical débridemen and cleansing, and complete immobilization, no general infection occurs. There is locally great microbiological activity, as is evidenced by the stench given off during the first three weeks (this is apparently the only objectionable feature of the treatment), but undesirable complications of bacterial origin-such as gas gangrene-are rare. The treatment is largely empirical; its justification is that it has worked. A history of the treatment and an analysis of its application to a large number of cases have been given by J. Trueta ${ }^{1}$, sometime director of the Department of Surgery in the General Hospital of Catalunya, Barcelona.

It could scarcely be expected that in the stress of civil war the microbiological changes could be examined in detail. It has been shown (loc. cit.) that the organisms in a plaster-treated wound are mainly aerobic, but no particular species or group of aerobes predominated, except that there was a tendency for 